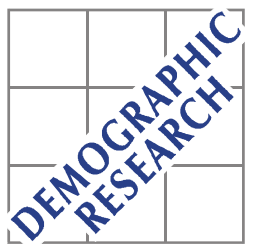

Demographic Research a free, expedited, online journal

of peer-reviewed research and commentary in the population sciences published by the Max Planck Institute for Demographic Research

Konrad-Zuse Str. 1, D-18057 Rostock · GERMANY

www.demographic-research.org

DEMOGRAPHIC RESEARCH

VOLUME 16, ARTICLE 12, PAGES 375-412

PUBLISHED 03 MAY 2007

http://www.demographic-research.org/Volumes/Vol16/12/

DOI: 10.4054/DemRes.2007.16.12

Research Article

High fertility Gambians in low fertility Spain:

The dynamics of child accumulation

across transnational space

Caroline Bledsoe

René Houle

Papa Sow

(C) 2007 Bledsoe, Houle \& Sow

This open-access work is published under the terms of the Creative Commons

Attribution NonCommercial License 2.0 Germany, which permits use, reproduction \& distribution in any medium for non-commercial purposes, provided the original author(s) and source are given credit.

See http:// creativecommons.org/licenses/by-nc/2.0/de/ 


\section{Table of Contents}

1 Introduction 376

2 Data and methods 381

$3 \quad$ Background 383

3.1 Immigrant fertility in contemporary Spain 383

3.2 Circulation of people in the Afro-Iberian corridor 385

3.3 Elements of West African political and reproductive regimes 388

3.4 Settling the Gambian immigrant frontier in Spain 390

$4 \quad$ Gambian immigrants in Spain 392

5 Discussion 399

$\begin{array}{lll}6 & \text { Conclusion } & 402\end{array}$

$\begin{array}{lll}7 & \text { Acknowledgements } & 404\end{array}$

Bibliography 405 


\title{
High fertility Gambians in low fertility Spain:
}

\section{The dynamics of child accumulation across transnational space}

\author{
Caroline Bledsoe ${ }^{1}$ \\ René Houle $^{2}$ \\ Papa Sow ${ }^{3}$
}

\begin{abstract}
Based on an analysis of the Spanish census and the January 1, 2005 municipal register and on exploratory fieldwork in Catalonia, this paper combines ethnography and demography, in conjunction with current Spanish reunification law, to examine the dynamics of what appears to be high fertility among Gambian immigrants living in Spain. We suggest that this high fertility rate reflects several things. One is the high costs of living in Spain for an unskilled, often-undocumented, but also relativelylongstanding SubSaharan group from a homeland with high rates of fertility: a homeland with which close ties remain vital for migrants in highly marginal conditions. Another is the replacement, in some cases, of older wives by younger ones from Africa, resulting in high rates of reproduction for short slices of time by a circulating pool of young women. We focus, however, on the role of Spanish and European policies themselves in shaping these numbers, particularly those policies that place restrictions on the free movement of people. We conclude that the most interesting demographic facet of this population may not be high fertility but rather the paradoxical dynamics of child accumulation in particular geographic regions as an artifact of Spanish law itself.
\end{abstract}

1 Dept. of Anthropology, Northwestern University, Evanston, Illinois, US. 60208 USA. E-mail:

cbledsoe@northwestern.edu

2 CRISP-RDC, University of New Brunswick, Keirstead Hall Building, 38 Dineen Dr., room 320 ,

Fredericton (NB), E3B 5A3 Canada, E-mail: rhoule@unb.ca

3 Grup de Recerca sobre Migracions, Department of Geography, Universitat Autònoma de Barcelona, Spain,

E-mail: investigation4@yahoo.fr 


\section{Introduction}

It is a remarkable fact that West African immigrants in Europe, coming from a region with some of the world's highest levels of childbearing, have fertility rates that are nearly as low as those of their host countries, a situation that characterizes that of many immigrant groups in Europe (Andersson 2004). Our starting question, stemming from a project on fertility and transnational vital events, ${ }^{4}$ addressed this puzzle specifically for Sub-Saharan Africa.

To investigate the phenomenon of low fertility among people from places of origin with high fertility, we chose Sub-Saharan African immigrants in Spain, which has now overtaken France as the leading host country for the people it classifies as immigrants, with 8.4 percent ( 3.7 million) of the population. ${ }^{5}$ The first Sub-Saharan Africans came to Spain in the fifteenth and sixteenth centuries as captives, brought by Arabs and Portuguese. $^{6}$ In the contemporary era Sub-Saharan Africans began to arrive in the late 1970's after Franco's death, though larger contingents arrived later as the country began to seek out male workers for industry and large-scale agriculture. Spain was also a destination of choice because of its geographic proximity, lower costs of living than in other EU countries, and the availability of jobs especially in agriculture, although most of these jobs are seasonal and undocumented. Following the recent disappearance of textile industries, the principal source of African immigrant male employment has become agriculture, despite its precarious nature.

Although African immigrants in Spain have higher fertility than do people of Spanish nationality, the apparent fertility of those who appear in the official sources the Census, the Municipal Register -- is far lower than in the countries from which they come. ${ }^{7}$ The possibility that immigrants from an origin locale with such a high fertility level would so dramatically reduce their fertility simply by changing continents raises the following questions: Do women come under new state pressures to use contraceptives? (See Sargent, 2005, on Malian immigrants in Paris.) Do children not appear in the official statistics because they have remained in Africa? Have Africans departed entirely from their former reproductive regimes?

4 http://www.demogr.mpg.de/general/structure/division2/lab-ceffd/156.htm

5 http://yaleglobal.yale.edu/article.print?id=5702

6 Detailed historical descriptions of Gambians in Spain are found in accounts such as those of Kaplan Marcusán (1998, ms.), Farjas (2002), and Rodríguez García (2001, 2002). For Africans more generally in rural Spain, see Hoggart and Mendoza (2000).

7 Roig Vila and Castro Martín (2005) in their comprehensive analysis of immigrant fertility in Spain, concluded that immigrant groups in Spain had overall fertility levels that were not significantly different from Spanish women, once age and other compositional variables were controlled. For basic data on demographic trends in Spain, see Instituto Nacional de Estadísta, www.ine.es. 
Kulu (2005), reviewing theories on fertility and migration, describes several approaches to consider for explaining the phenomenon of migrant fertility reduction in the new context. One explanation centers on forces of disruption, whereby immigrants delay or reduce the production of children in order to carry out the move. Alternatively, adaptation may explain the shift to lower fertility, wherein immigrants, over time, become subject to the same costs of bearing and raising children that citizens encounter and reduce their fertility accordingly. A related possibility is assimilation: the strength of a new context in overriding old ways of thinking. ${ }^{8}$ Equally plausible for explaining low immigrant fertility are forces of selection. Those migrants who come to Europe might be more likely under any circumstances to have low fertility than those who stayed home. People who become migrants may have more education or a stronger professional orientation than non-migrants, and female students who migrate may not wish to jeopardize the goal for which they came by getting pregnant. Migrants may simply be those who have less interest in large families than those who stay; conversely, people who have already had a child in the country may be less likely to leave the country. Of course, selection forces may work in opposite ways by increasing rates of fertility. Yavuz (2005) reports that fertility among Turks in Germany is even higher than among Turks in Turkey, possibly because of the region of the country they come from or because many of the women who come to Germany have come precisely to marry and have children. In Sweden, Andersson (2004) reports that women from several immigrant groups who typically arrive as brides for earlier-arriving men are expected to begin reproduction as soon as they arrive. ${ }^{9}$ Regardless of which direction the post-migration rates go, the problem that such studies have begun to highlight is that while reproductive life takes place within specific temporal frames, its events are conventionally calculated by assuming a fixed place or context. Studies of vital events through time have produced some of the greatest works in the social sciences. ${ }^{10} \mathrm{~A}$ major new challenge is to link time with place, asking how people distribute their temporalized vital events such as birth and marriage across space (Bledsoe, 2004).

In our case, as the research on Spain progressed, a quite anomalous group increasingly drew our attention: Gambians. ${ }^{11}$ Gambians were among the first SubSaharan immigrants to Spain in the post-Franco era. While Gambians who are educated tend to go to the U.K and elsewhere in Europe as students and skilled workers

8 Pursuing the unexpected logics of another facet of assimilation, Frank and Heuveline (2005) argue that increases in fertility among Mexican immigrants to the U.S. may stem as well from racial discrimination, which may impede a package of assimilation behaviors such as low fertility.

9 See Coleman (1994) on overall observations of immigrant convergences with fertility levels in the new location.

10 See, for example, Durkheim (1915), Evans-Pritchard (1940), Halbwachs (1980), Ryder (1965, 1992), Bongaarts (1978).

11 In this paper we refer to "Gambians in Spain," though we distinguish, when appropriate, between individuals with Gambian nationality and Gambian-born individuals. 
(Rodríguez García 2002), many of those who come to Spain are unskilled, uneducated agricultural workers from rural eastern Gambia, far from the coast (Kaplan Marcusán 1998, Farjas I Bonet 2002). In Spain, Gambians are a group of modest size. As of Jan 1, 2005, municipal registry data compiled by the Instituto Nacional de Estadística showed 15,745 Gambian nationals (or Gambians by citizenship) in Spain and 11,548 individuals born in The Gambia (www.ine.es), these being non-mutually exclusive groups. Both are surely underestimates, however, since many Gambians (like members of many other African groups) are undocumented. ${ }^{12}$ They are concentrated into just one of the country's seventeen Autonomous Communities: Catalonia (population nearly seven million as of Jan 1, 2005), in the far northeast of the country. Fully 83 percent $(13,052)$ are registered as living in Catalonia: Barcelona (4864), Girona (7070), Lleida (1030), and Tarragona (88). With an established Gambian community now in Catalonia, most new Gambian arrivals to Spain come to Catalonia (Kaplan Marcusán 1998).

What is so striking about Gambians in Spain is that they appear to have by far the highest fertility rates for any national group in the country. Based on the 2001 census, we estimated the total fertility rate of the Gambian-born population, using the "ownchild" method, to be 3.67 children per woman for the period 1996-2000. ${ }^{13}$ Gambians have a TFR in Spain that is much lower than in The Gambia: 5.46 in 2004. ${ }^{14}$ Still, it is considerably higher than any other immigrant group of any numerical significance. Senegalese are next with a TFR of just 1.92, followed by Moroccans and Algerians with 1.50 and 1.28, respectively. Gambians effectively have fertility levels that are nearly twice as high as those of any other nationality, in a country with one of the lowest fertility rates in the world. ${ }^{15}$ Our initial question -- why is the fertility of African immigrants in Spain so low? - thus became, Why is the fertility of Gambian immigrants in Spain so high?

12 See Recano-Valverde and Domingo (2005) on a technique for estimating such numbers in Spain. 13 The work of Kaplan Marcusán et al. (2000-2002:65) in the town of Mataró, using a sample of 124 Gambian women, aged 30.7 on average, revealed an average of 2.81 live births from a clinical history, and 2.74 according to study interviews. Using an overlapping Mataró sample of 154 women from The Gambia, Senegal and Mali, Merino Tejada (2003) noted that Gambian immigrant women, who have a longer history in Spain than those from Senegal, appeared to have higher fertility levels: 4.1 children per woman vs. 3.0 (p. 106). Combining all three countries, she also found differences in rural vs. urban backgrounds among women from these countries (3.2 vs. 2.9, respectively) as well as ethnic differences: Mandinka women had 4.7 children, compared to 4 for Sarahulli (p. 117). At the other extreme, Andreu Domingo, using the standard TFR method, based on the total female population from the 2003 "Padrón Continuo," found a Gambian TFR of 6.9, though he believes this to be an overestimate (pers. comm.).

$14 \mathrm{http} / / /$ www.country-facts.com/africa/Gambia-people.php, accessed July 16, 2005.

15 Systematic information on fertility rates among African immigrants in other European countries is scarce. Toulemon (2004) calculated the following TFRs for various immigrant groups in France: 2.57 for Algerians, 2.97 for Moroccans, and 2.86 for other Africans. Compared to the fertility rate of Gambians in Spain, however, these numbers are decidedly low. 
One interpretation of the phenomenon might center on a model of "customary practice." That is, once family reunification made it possible to bring spouses, Gambians in Spain, clinging to the ways of life they experienced in Africa, could have begun to replicate the high fertility reproductive practices from their rural homes. Such a view, however, quickly falls short. Africans have displayed tremendous versatility in improvisation for as long as we have historical records (Guyer 2004). Further, Gambians in Spain have fertility levels that are much higher than those of immigrants like Senegalese or North Africans, who experience no less insecurity and whose TFR's are far below those in their own home countries. One explanatory strategy might center on the legitimacy that bearing a European-born child may confer (Bledsoe 2004). Bearing Spanish-born children may not offer immunity from deportation, but it does seem to give an African woman greater confidence to place herself in the municipal register, thereby acquiring eligibility for social services and agencies to turn to if her husband tries to send her home. Taking steps toward the legitimacy that her Spanishborn children can facilitate, she can move from the shadows into public spaces. While this theory seems plausible, bearing just one child could confer such legitimacy, and it would not account for the far greater number of children that Gambian women in Spain seem to bear, compared to other African women.

To investigate the anomaly of high Gambian fertility in low fertility Spain, this paper combines analyses of the national 2001 Spanish census and the annual tallies from the municipal register, together with exploratory field studies in the Barcelona area and a reading of the available literature. The challenge is to comprehend mutually entailed life course trajectories of individuals across international space, when the measurement of life events inevitably reflects selective entry into, and exit from, groups. To complicate matters further, many of these selections appear to be intentional: during such "acts of selection' (Bledsoe, ms.), actors make choices in anticipation of certain outcomes with the goal of producing others. In such cases, the matter is best seen not as a problem of statistical misconstrual, requiring a search for variables to control or rule out, than a window of opportunity to explore the conjuncture of the social factors that themselves produce the apparent selective oddities. ${ }^{16}$

There are now numerous publications on social life conducted across national spaces, whether one goes back to the classic 1970s works on notions of core and periphery in a capitalist world system (Wallerstein 1974), or considers Beck's (2002) invocation of "place polygamy" or Vertovec's (2002) "bifocality," all evoking multiple attachments and orientations to multiple locales. For understanding immigrant dynamics, Wimmer and Glick Schiller (2003) and Levitt and Glick-Schiller (2004) express skepticism about what they term "methodological nationalism," a kind of "country as container" approach that assumes that the forces that shape behavior form a

16 See especially Johnson-Hanks' notion of “vital conjunctures (2005). 
coherent package within each nation state. In their vision, social relations and institutions that traverse national space are key. Developing a concept they term "transnational social fields," which encompasses structures of solidarity as well as exploitation, Levitt and Glick-Schiller (2004) emphasize a "simultaneity perspective," to accommodate the realization that individuals can lead their lives in ways that "incorporate daily activities, routines, and institutions located both in a destination country and transnationally" (ibid.). Transnationalism and its subsidiary concepts offer anchoring points into more intense looks at home and destination locales as well as the complicated links that join them. ${ }^{17}$ These perspectives suggest that people may need to move across national borders to pursue not just employment but their more demographically relevant agendas of marriage and reproduction. Conversely, they may have to split their temporally arrayed lifecourse events across space, and even create new lifecourse elements that may bolster their claims to gain legitimacy in the new place.

It is critical, regardless of approach, not to understate the role of the home context or to simplify relations with it. In the present case, we believe that the sharp constraints of life under the difficult and often-undocumented conditions faced by Gambians in Spain make the retention of close social ties with the home country essential. This does not mean that obligations are always fulfilled, nor does it mean that there are no attempts to thin out these ties, when necessary. Nonetheless, negotiating the precarious new environment demands deep, continuing engagement with the home country, itself changing rapidly, in economic support, political alliances, and fluid exchanges of people: especially through marriage and child fostering. We will suggest that the large numbers of Spanish-born Gambian children who appear in the official sources in Spain can be traced largely to three things: a series of apparent reporting oddities, the economies of life that families with children attempt to find in the more "rural" or "regional" areas of Spain, and the idiosyncracies of Spanish policies themselves. However, all manner of forces must be in play as Gambian immigrants, many of them undocumented, pursue a reproductive life across transnational space. All come together most compellingly in struggles over boundaries: not just physical ones but social ones, and their potentials to exclude as well as include.

This paper takes a series of ethnographically informed slices, using some highly descriptive demographic tools, to interpret a body of exploratory empirical work on anthropology, demography, and the law. Doing so begins to open up a fascinating picture of reproductive life in the margins of Europe. Although the fertility consequences seem unique to Gambians, we believe that the dynamics of exclusion that this case brings to light are far-reaching for understanding the dynamics of immigration

17 On the anthropological theme of connection to home, see, for example, Constable (1999), Glick-Schiller and Fouron (2001), McMurray (2001), and Whyte (2005). 
to the E.U. more generally, including that of groups that do not exhibit the same high fertility.

\section{Data and methods}

For information on African nationals born abroad and those born in Spain, we relied on a number of sources. Spain has no publicly available national fertility surveys with samples large enough to capture most immigrant groups, so we used a five percent sample of individuals from the demographic Spanish census of 2001. This sample contains information on the nationality of individuals, country of birth, and year of arrival in Spain. ${ }^{18}$ It also contains information on relationship of household members to the household head, including the identification of children with their parents, and conjugal partnerships. We also rely on aggregated information from municipal register data (the "padrón"), available from www.ine.es.

The quantitative sources have clear limitations. In both the census and the register, we can distinguish foreign-born people who now hold Spanish citizenship, but we do not know when they acquired it. We also cannot tell from the register data which children belong to whom, though the census micro-data links adults with their own children, as long as they live in the same household. There are also differences in coverage among sources. The census in theory enumerates the entire population although it misses many undocumented immigrants. The registry data, compiled annually, represent those people who come forward to announce their presence to municipal authorities in order to be eligible for local social services. This they can do allegedly without fear that their personal information will be disclosed to the immigration authorities, though declarations of place of residence by the registrant and ties to those whom he/she claims as dependents are sometimes based on thin claims. While censuses tend to under-enumerate foreigners, therefore, registers over-enumerate them. Neither the census nor the municipal register, however, ask women how many children they have borne. Hence, our attempts to calculate total fertility rates (TFR) for some countries from the 2001 census used the own-children method (Preston and Palloni, 1978): using age groups from children present in the household who can be matched, in the micro-data 5 percent sample file, to a woman of a particular age who is reported as the mother. ${ }^{19}$ With many immigrant women having borne their first

18 See Roig Vila and Castro Martín (2005) for an extensive analysis of immigration in Spain using these materials.

19 http://www.ine.es/prodyser/microdatos.htm. The method, of course, has defects. Because parents sometimes do not report the births of dead children and very young children, it underestimates fertility rates. In particular, it may underestimate the fertility of immigrants, whose status is less secure than that of 
children in Africa, where mortality rates are higher than in Spain, and with unknown rates of fostering both into and out of households, the weaknesses in the "own-child" method loom large. At the same time, confronting the social and demographic significance of the fluidity and instability of households containing West African families in Spain is a key agenda of this paper. Indeed, even age-sex pyramids like those we employ can be misleading: they do not necessarily comprise self-contained populations whose members are either stationary or related to one another in predictable ways. Reflecting self-declarations of citizenship and residence, they are nonetheless powerful visual representations of the social and temporal politics of "belonging" in an alien context.

Equally important sources for this paper were the published ethnographic and social literature on African immigrants in Spain, and our collective personal knowledge and professional experience working in Africa and Europe. Some of the most revealing sources of information for the study arose in several weeks of exploratory fieldwork in the Comunitat Autònoma de Catalunya (the Autonomous Community of Catalonia) in July, 2005, and in subsequent interviews by Papa Sow. We focused on the city of Barcelona, turning attention later to a nearby regional town. In Barcelona, we consulted scholars, clinic workers, NGO personnel, and members of several immigrant groups. To understand and contextualize these discussions, we used diverse methods ranging from in-depth exegesis of single cultural terms to the crunching of large numbers from the internet. Regardless of the method or its disciplinary origin, we worked iteratively, seeking insights from attempts to mine the empirical findings and explore their structures. All sources - numbers, interviews, casual conversations, observations, circumstantial evidence - were constantly checked for consistencies and anomalies, to derive new interpretations.

As for interviewing Gambians themselves in Spain, especially women, finding them and persuading them to talk to us proved a difficult task at first. People at the margins of legality do not particularly want to be found by researchers. Several prospective interviewees melted away or somehow failed to appear. On our first field sojourn, for example, we were able to interview just one Gambian: not a woman but a man in his late 40's who had spent a life of low-paid agriculture work. Ever on the move, he had lived and worked in a number of African and European countries. Though he managed to visit his wife back in The Gambia occasionally and to father four children, such a marginal existence kept the goal of bringing his family to Spain

nationals. To try to control for children who may have been left behind in a migration move and for the omissions of recent births, we restricted calculations to 10 years preceding the census (to include children no more than ten years old at the census), and we excluded any time period preceding the arrival of the mother in Spain. We also excluded the youngest children by excluding the year the second half of the year 2001 (JulyNovember). The reasons for this were that the year 2001 is incomplete (the census began in November and continued until the next month) and that young children are often undercounted. 
perpetually out of reach. The interview with this illiterate, undocumented, unaccompanied man proved to be a turning point in the study.

\section{Background}

\subsection{Immigrant fertility in contemporary Spain}

According to the 2005 municipal register figures, about 90 percent of the Spanish population in January 2005 consisted of individuals born in Spain; about the same percent have Spanish nationality. Of the total born elsewhere, those born in five countries (Morocco, Ecuador, Romania, Columbia, and the UK) comprised 43 percent. For decades, Moroccan-born individuals have constituted the highest percentage of foreign-born individuals. They now make up 13 percent of the foreign-born population in Spain, though Ecuador and Columbia have moved up rapidly in the distribution. People born in The Gambia, mostly men, at 0.3 percent of the entire Spanish population, are $40^{\text {th }}$ among the ranks of the foreign-born with less than 11,889 individuals. Individuals with Gambian nationality (including individuals born in both The Gambia and Spain) number 15,838. Children born in Spain of foreign-born parents do not receive Spanish citizenship automatically. Apart from Equatorial Guinea, a former Spanish colony, and Guinea [Conakry], all the other Sub-Saharan-origin individuals from the top-50 group of immigrant-sending nations (Senegal, Nigeria, Gambia, Mali, Ghana, Mauretania) have less than four percent of individuals with Spanish nationality.

Lowest fertility occurs among the recently arrived - examples: Ecuadorians, Eastern Europeans, Russians. Figure 1, using the own-children method with the most recent census data (2001), shows the total fertility rates for a selection of foreign-born immigrants in Spain by two time blocks: 1991 to 1995 (blue bars) and 1996 to 2000 (red bars). The sets are sorted by the most recent figures, flowing in descending order from immigrants with the highest to the lowest fertility. The results show two things. One is the striking difference between the fertility rates of individuals born in The Gambia compared to other groups. With a TFR of 3.67, Gambian-born women have three times as many children as Spanish-born women. Second, the combination of the red and blue bars, showing the changes since the first and second halves of the decade, reveals not only that Gambian fertility is high relative to the other groups, but it has apparently risen over the decade. Among all immigrant groups in Spain, this is highly unusual, though we show several others in this chart that have also risen, including those from Morocco, the Netherlands, and the Philippines, the only other groups that has risen at a rate around the same as that of Gambians. 
Figure 1: Selected total fertility rates of various nationalities in Spain, 1991-1995, 1996-2000.

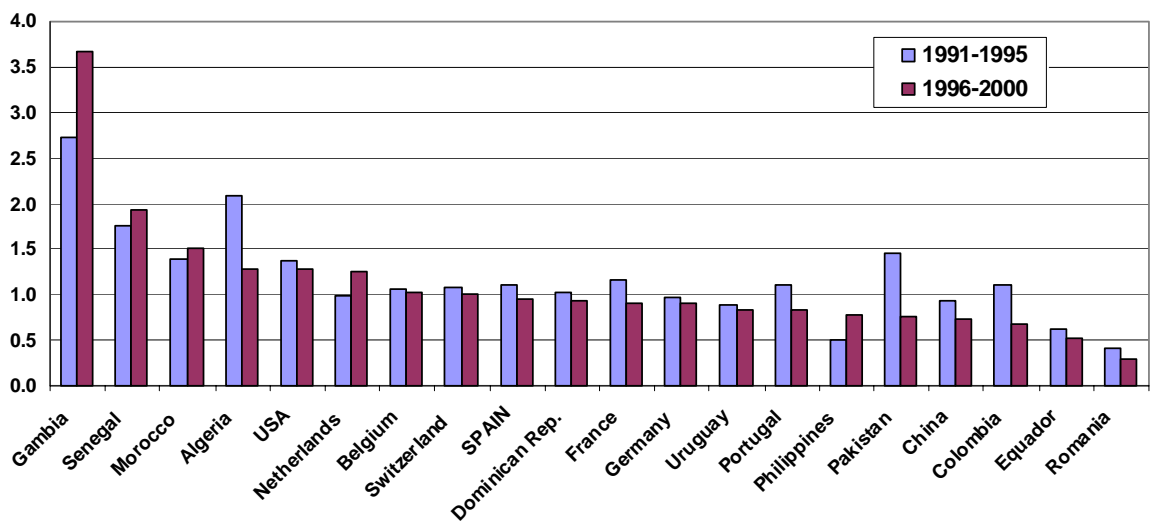

Source: Censo de Población y Viviendas 2001

Just these few examples reveal immense variation among immigrant groups in Spain. Whether these differences stem from responses to immigration law and practice, from assimilation pressures, or from the imprint of the home country, one cannot say. What we stress, however, is the substantial methodological risk of assuming that these numbers describe self-contained populations whose members are both stationary and related to one another in straightforward ways. Numbers like these are illusory. Whereas they might appear to represent coherent, homogenous, self-contained groups -even families -- in reality, the members of the pyramids are connected to each other by just one characteristic: country of birth or country of nationality among people who appeared in the Spanish register in 2005. Except for the age and sex attributes that will position them within their respective charts, the people in these graphs have no other necessary commonalities. Large proportions of individuals who might be expected to make conjugal partnerships across a particular pyramid's gender line may not be connected at all, adults depicted in a pyramid may be unrelated to the children below them, and children who were sent back to the home country may be out of vision altogether. We might even speculate that individuals whose nationality pyramids have high proportions of undocumented members may be least likely to be related to one another in regular or unique unions, or by stable parent-child connections. All these cautions and more are highly pertinent to Gambian immigrants in Spain, whose marriage and fertility numbers provide just one of many available windows into the magnitude of immigrant struggles to manage in a new land. 


\subsection{Circulation of people in the Afro-Iberian corridor}

With its industry, farming, and critical geographic proximity to the rest of the EU, Catalonia has become the economic powerhouse of Spain. The seacoast has harbors, fisheries, a large service sector, and a booming tourist trade especially in Barcelona, the Community's capital. ${ }^{20}$ Major industries in the recent past have included chemicals and the manufacture of automobiles, airplanes, trains, and metal items. Clothing and textiles, the former principal money earners for the Community, have gone into decline with the opening of global markets to China. Agriculture remains a backbone industry. Catalonia produces cereals, potatoes, maize, olives, grapes, and a significant proportion of the country's wines. In recent years, a number of organic farms and commercial greenhouses, invernaderos, have sprung up to grow food and flowers for Spanish cities and for the EU market just across the border. Catalonian agriculture, like that of Spain as a whole, is heavily reliant on low-cost seasonal labor of the kind that many Gambians and other Africans now provide.

As for Spain itself, the country was one of the most formidable colonial powers in history, generating centuries of migration, through commerce, conquest, education, and missionization, to the New World, Asia, and the rest of Europe. Well before the twentieth century began, the country became a labor exporter, its economy deflated by the loss of its colonial holdings, based largely on agriculture. Scholars of Spanish migration history have traced Spain's dramatic economic reversal, during the last quarter of the twentieth century, to several things, among which the most important was probably the demise of the deeply conservative government of Generalissimo Francisco Franco. With Franco's death in 1975, manufacturing, tourism, industry and large-scale agriculture opened up, and with them, a demand for low-cost labor. Young Spanish citizens, however, much preferred skilled jobs and life in urban and industrial areas. To add to the economic complications, the end Franco-era bans on contraception and divorce brought about a decisive drop in fertility: from 3.0 in 1964, the TFR declined to 1.4 by 1994 (Miret 2000). By the time Spain entered the European Union in 1986, its farms and businesses began actively to seek to labor particularly for unskilled jobs in manufacturing and farming. The country has thus transformed from a country that exported its young labor into a destination country for fresh, cheap labor to supply its booming economy.

On the wider European scene, the Schengen agreement of 1985 opened free passage to citizens of E.U. member countries, allowing short stays for citizens of nonmember countries, following a legitimate entry into one of the E.U. signatory countries.

20 See Cabré (1999) for a description of the dynamics of reproduction in urban Catalonia. For discussions of immigrant dynamics in urban Catalonia, see Domingo et al. (1995) and Domingo et al. (2002). For discussions of immigrants in the surrounding comarques, see Domingo and Brancos (1996). 
As more restrictive policies began to appear, however, especially the Treaty of Amsterdam (1999), Spain's geographical proximity to Africa began to make it a point of attempted transit for many immigrants to the rest of the EU, where they could travel more freely. Within Spain itself, some African immigrants have drawn fair and decent conditions. Those who are undocumented, however, have tended to work in arduous, underpaid, precarious agricultural jobs in the south, moving from one seasonal job to the next. And the E.U. is exerting growing pressure on countries at its own borders, especially Spain, to control the flow of migrants at its borders. The effects of such pressures are by no means straightforward. Works from the Mexico/U.S. borderland (Massey et al. 2002; Massey 2004, 2005; Lamont and Molnár 2002) on the paradoxical effects of boundary-making have shown that the number of Mexican residents in the U.S. has swelled in the last few decades not because increasing waves of migrants have surged toward a permanent life in the land of riches. Instead, many Mexicans who might otherwise prefer temporary work in the U.S. and a life of circular migration end up settling in the U.S because of the heightened risks of being detained or deported if they attempt to re-enter. Most Gambians who come to Spain are unskilled workers whose home country offers far less economic opportunity than Mexico. If, however, the case of African migrants in Spain mirrors that of Mexico/U.S. borderland efforts to restrict immigrant numbers by making entry more difficult, the residence question increasingly hinges more on what is to lose by leaving Spain rather than on what is to gain by coming. The result in Spain, as in the U.S., may actually be an increase in the size of the immigrant population by lowering the rate of out-migration.

Although immigrants like these have drawn antipathy in Spain, their plights have also drawn concern. Much of the impetus for efforts to aid them have built on UN and regional family reunification doctrine. Family reunification refers to the process whereby the family members of a legal migrant - whether they became kin before or after the migrant's move -- join him/her in the new country of residence. ${ }^{21}$ Although most family reunification instruments allow signatory states to interpret international conventions according to their own national codes, most countries set a maximum age of 17 on children who can join a parent, and for spouses (no more than one) a minimum age of 18 .

In 1985 Spain enacted its first major law on migration policy: the La Ley de Extranjería, the Law on the Rights and Freedoms of Foreigners in Spain. ${ }^{22}$ A 1996 amendment recognized that foreigners had rights to education, equality, and legal counsel, and it established a permanent resident category. This amendment also incorporated an allowance for family reunification ("reagrupament familiar"). Spain's family reunification policy allowed foreigners who had had legal residence for at least

$21 \mathrm{http} / / /$ www.ohchr.org/english/issues/migration/taskforce/docs/familyreunification.pdf $22 \mathrm{http} / / /$ www.migrationinformation.org/Profiles/display.cfm?ID=97 
one year to petition to bring relatives who were still in the country of origin. These relatives could include dependent parents, a spouse, and any unmarried children (biological or adopted) under 18; if these were children of only one of the spouses the one requesting family reunification was required to have custody. Once a spouse gained legal residence, he or she could stay even if the marriage later dissolved. Such people needed proof of their relationship with the family member and proof that he/she could provide for them in Spain. ${ }^{23}$ Spain requires ten years of residence to apply for naturalization. Few opportunities are available for skilled workers or students, so most immigrants seeking permanent residency in Spain come through asylum or illegally, hoping to regularize to gain legal status. ${ }^{24}$ The implementation of these accords, however, has been uneven and, like any policy measures, can effectively exclude as well as include. For some time, for example, there was a 5-year ban on employment for an immigrant's spouse brought legally through reunification, a measure that largely increased participation in a thriving underground domestic economy among women who engage in low-paid labor in cleaning, caring for children and the elderly, and so on (Kaplan Marcusán 1998; Sow 2004b).

With its need for both labor and contributions to its social security systems, Spain has offered four amnesties in the last two decades. The last, and most comprehensive of these, ending in May 2005, granted nearly 700,000 employed workers legal residence. ${ }^{25}$ The aim particularly in the last amnesty was to undermine the black market in exploited labor, and to increase the employer share of contributions to workers' social security and health benefits. For those immigrants who qualified, this last amnesty gave them more rights, not the least of which was the freedom to travel more freely both within and out of the country. However, it also tied security explicitly to a legal job contract, leading some employers to fire workers before the amnesty window arrived so they would not have to pay benefits. The fact that migrants could not seek work visas or residency permits until they had a job offer was particularly problematic, and immigrants without evidence of residence became illegal by definition almost as soon as the policy became effective. The new measures, in tying the security of dependents even more tightly to the job of one person, produced what may have intensified the vulnerability of women and children to being sent home by the wage earner or even to domestic abuse. The evolving corpus of rules has also had more subtly distorting effects on marriage and reproduction. To set the context for this claim, we turn to the West African cultural setting.

23 http://www.geocities.com/CapitolHill/Parliament/4327/ppascr16.htm

$24 \mathrm{http} / / /$ www.migrationpolicy.org/news/2002_02_22.php

25 A number of registrants in the 2005 amnesty were said to come from other parts of Europe, seeking the legitimacy that would allow them to live and travel within and out of Europe, by Schengen terms, and leaving as soon as they obtained it. 


\subsection{Elements of West African political and reproductive regimes}

Three key domains in West African social and reproductive life -- marriage, the production of children, and the founding and settlement of a political frontier - are key modes through which relations take place across the Afro-Iberian divide. All stem from, and generate, flux in time and space. These great "circulation" models stretch demographic ways of thinking. They also mesh poorly with the narrow, static definitions of spouses and biological children, the basic categories now allowed under family reunification schemes in Europe.

The movement that marriage generates is a prominent feature of all the classic ethnographies of Africa. For a man, marriage is the first step toward both reproductive life and a political career (Clignet 1970). In most African societies, however, it is the woman who leaves her home to come to that of the man. A wife is expected to keep the home, work on the family farm, earn income through petty trading, provide hospitality for important visitors, and bear children who will propagate her husband's identity and honor. A woman, for her part, may marry soon after puberty, typically moving to the husband's home and beginning childbearing shortly after. A young wife sees children as the key to security in her husband's home and a bulwark against competition from present or future co-wives. She may try to bear a series of children as quickly as possible without risking their health and her own. At some point, however, she becomes physically "spent" from her reproductive exertions, regardless of her chronological age, and begins to run severe health risks for each subsequent pregnancy. Her husband, if he is responsible - and if he believes she has been deserving -- should allow her to retire from childbearing, and even allow her to return home to her own family, if she so desires. Jealousies among co-wives and charges of male favoritism can be sources of bitter tension in polygynous households (Randall and LeGrand 2003, Lardoux and van de Walle 2003), and a man may use his wife's "aging" as an excuse to marry a new woman. But a husband who does not bring home a new co-wife to take over the productive and reproductive burdens for a faithful wife who is worn out from childbearing may come home one day to find she has gone out and secured one for him anyway. (See Bledsoe 2002, on the intertwined politics of polygyny and aging.) Rates of polygyny appear to be declining in Africa, with education and urbanization, and a number of countries have formally banned the practice. But the forces that demand alliances to diverse groups through conjugal ties, among others, remain powerful. Hence, forms of sub-rosa polygyny -- informal plural unions among residentially separate partners (Locoh 1994), "serial monogamy" (Comaroff and Roberts 1977), and the acquisition of young partners by "sugar daddies" (Dinan 1983) -- continue to flourish across the continent (Parkin and Nyamwaya 1987, Sargent and Cordell 2003, Fleischer 2005). 
Like the marriage practices that move women, fostering practices create enormous mobility among children. Legal adoption is almost unheard of, but fostering out children to live with relatives, friends, or teachers is regarded not only as normal but advantageous for both children and their families. Families enact fostering arrangements for education, apprenticeship, ritual initiation, Arabic instruction, or household help, or simply to gain assurance of future reciprocity among a wide kin network. Even small children in West Africa are often sent to a grandmother for several years, either because they are ready for weaning and the mother is ready to begin a new pregnancy, or because the parents need to work. So commonplace is the practice of fostering that the same parents whose own children are away may be taking care of other people's children. In fact, with the exception of grandmothers, who are notorious for spoiling children, outside guardians are sometimes said to be better disciplinarians than parents: more willing to instill children with fortitude to steel them to difficulties in the future (Goody, 1973; Bledsoe, 1990).

Men of course move as well, though most notably to look for work. So important is marriage that young men in Africa often leave home for long periods to work for bridewealth to secure rights to a woman's labor and reproduction (e.g., Enel et al. 1994, for the Joola of Senegal). Among the most interesting forms of mobility precipitated usually by men is the phenomenon of settling a "frontier." Political incorporation is a longstanding theme in the African ethnography (e.g., Shack and Skinner et al. 1979), emerging vividly in oral histories of the founding and settlement of a new "frontier" (Kopytoff 1987). In Liberia (Murphy and Bledsoe 1987), oral histories of a polity typically depict a first-comer/founder's act of exploring an unknown new land, securing it from enemies and dangerous ritual forces, renaming it to symbolically establish its new identity, and clearing it for farming. Acquiring a wife to work on the farm and bear children, this founder begins to strike allegiances with newcomers seeking similar security, assigning them territorial sub-domains to administer, and giving them one of his daughters or sisters - or a client's daughter or sister -- in marriage. He can also give them a woman from a client's family - a woman who is effectively his daughter. Through the relationships it creates between the two families in the present and particularly the next anticipated generation, such a marriage creates a perpetual matrilateral line of subordinate "nephews" or "newcomers" to the original "uncles" or founders. In later years, subsequent newcomers may be placed under the jurisdiction of the original nephew, receiving further sub-domain to consolidate from the original newcomer - and now himself part of the "founder" hierarchy -- and women to marry. The result is a nested political structure knit together by the idioms of marriage, kinship, and territorial expansion and consolidation. ${ }^{26}$ Circumstances like these vividly remind

26 Similar patterns and their linguistic indicators emerge throughout Africa. In the languages of The Gambia, linguistic terms link superordinance with territorial precedence and with matrilateral kinship. In Serahulli, 
us that any conception of "family formation" as the outcome of free choice by a couple detached from a social and political milieu is misguided, regardless of which society we are describing.

The notion of frontier of course connotes expansive untamed rural wilderness to Western audiences. But the process of carving a "civilized" territory anew out of a frontier extends to urban settings as well: places where many previous people who call themselves founders and their followers have lived for some time. Barnes' (1987) study of the rise to power, from the marginal migrant ranks of a new local government in the Lagos suburb of Mushin, in the 1950s and 1960s, details the process by which a narrower group supplanted its rivals, took over the ranks of chiefly authority and replaced the ranks of chiefly titleholders with newcomers, who fictionalized themselves into "traditional" authority. The study is notable for many reasons. Not the least is that this occurred in a highly urbanized suburb of the biggest city in Nigeria: itself the most urbanized country in Sub-Saharan Africa. A "frontier," in sum, can comprise not just unexplored, untouched lands, but fully inhabited named urban areas with complex social orders and deeply entrenched histories. All lies in the eyes - and agendas - of the newcomers.

\subsection{Settling the Gambian immigrant frontier in Spain}

People never replicate past patterns simply because of tradition. However, ties created through the idioms of marriage, fostering, and patronage provide key resources on which African migrants draw to settle what is for them the "Spanish frontier," a daunting world of employers, landlords, and civil bureaucracy. It was on precisely such matters that our interview with the Gambian man mentioned in the introduction turned so powerfully. At the heart of his comments were references to patron-client relations, particularly those centering on the struggle to attain legal status in Spain, as well as to the kinship and marital ties established through marriage. In the wake of his comments, a highly consistent picture of life for would-be Gambian settlers in Spain came to life in all our subsequent interviews, and literature and statistical analyses.

The problems that African immigrants confront in Spain can be illustrated by describing the formal steps toward regularization for an African worker (assuming a man) and his family. The trajectory includes registering at the Civil Government to get a residence permit (what people refer to as "papers"), getting a job contract, and applying for family reunification: each, for an African, a formidable undertaking. Of

from eastern Gambia, hiiri means "old persons," "experienced persons," "firstcomers;" in Wollof, there is "diatigui" ("elders," "experienced," "firstcomers," "uncles") vs. "dahar" ("youth," newcomers," "latecomers," "nephews"). See also Sow, (2004a). 
particular importance is the job contact, which gives a man the right to apply for a work permit and for a health insurance card, a social security card, and a residence permit. It also persuades his landlord that he can pay his rent. All this he must have in place to move to town and bring a wife and children. But getting a job in Spain, like everything else, requires the careful cultivation of patronage networks, staying in good stead with thick layers of friends of friends, whether by payments or favors or, in some case, providing a wife. A prospective worker must be well positioned, in case a Spanish employer needing laborers suddenly asks an employee to mine his networks for job candidates and help negotiate the terms of their work (Pau Baizan, pers. comm.). ${ }^{27}$

With spiraling immigration and employment challenges, it should not be surprising that how African immigrants describe their difficulties in coming to Spain and attempting to "regularize" their status (regularizarse) bear striking resonance to how they describe settling a frontier in Africa. Among the most surprising, at least to an outsider, is that of "renaming" elements of Spanish geography - a town, a neighborhoods, and even Spain itself - often in the names of those Africans who first "settled" them mere decades ago. In this new immigrant frontier, however, the acquisition of papers becomes the consummate prize around which relationships of kinship, ritual, and precedence arise.

Needed by such immigrants is the intervention of a broker who speaks the local languages (in the case of Catalonia, both Spanish and Catalan); who already has papers, knows sympathetic officials and humanitarian groups; and is familiar with both the formal rules of the system as well as the strategies that allow one to maneuver within it. Such an individual can help a newcomer to grapple with hurdles that a Spanish citizen would find quite ordinary tasks, such as finding a place to stay and eat, not to mention negotiating a job, getting papers, and trying to grasp the mysteries of an utterly foreign language. (See Sow 2004a, on the parallel efforts by Senegalese traders in Spain to become established.) He can also help them to bring their own dependents, though there is usually an expectation of payment, currently said to range upward from three to four thousand euros for time, expenses, and risk. Each newcomer who manages to establish himself by obtaining a job, papers, a flat, and a wife, in turn becomes a patron/uncle to subsequent newcomers, helping them to get their own jobs and papers, and to bring their other wives and dependents from Africa. Indeed, a man from Africa faces enormous pressure to help others from back home to come, both to reciprocate to the family members who supported him in the past and also to move others into positions in which they can share the burden of family support.

27 This suggests that the nature of labor recruiting itself can produce immigration streams from specific places, especially as local labor markets become transnational (for analogous discussions, see Sassen, 1995). See also Krissman's (2005) observation on immigrant transnational networks that include employers. 


\section{Gambian immigrants in Spain}

Many Gambians may see Spain in the long-term: a place to work, gain residency, and raise a family. ${ }^{28}$ The case of a nine-year-old Spanish-raised Gambian boy dying of malaria shortly after he returned to The Gambia for a visit made a deep impression on the Gambian community in Spain (Farjas i Bonet, 2002). Spain may be expensive and politically intimidating to its Gambian residents, but no one questions the health advantages of living in Spain for children as opposed to living in The Gambia. Like many other Sub-Saharan Africans, they also entertain the yet-more long-term hope of returning to Africa when they retire. Sending home remittances and making visits when possible is aimed to help their families and to ensure a warm welcome from grateful, supportive kin after work life is finished. The hope of returning to a life of honored retirement, however, is often a myth that the harsh realities of immigrant life make impossible to realize (see Kaplan Marcusán 1998:179-81; and Rodríguez García 2004:72-73). They face treacherous crossings over the Straits of Gibraltar, border controls, exorbitant expenses, grueling living and working conditions, and minimal competence in the language and practices of the host country. With a high adult gender imbalance among eligible conjugal partners in Spain, Gambian men may find themselves in dispute over women. Many relate a convoluted employment history of precarious, erratic jobs patched together across Africa and Europe, earning barely enough money to stay out of debt, much less send home regular remittances or bring a wife from Africa. For Gambian women, who typically come through reunification, there are reports of forced marriages, ${ }^{29}$ "white marriages" (on-paper only), spousal abuse, and conflicts with unwanted co-wives. Many people also report instances in which a man may send his older wife back to Africa or allow her to remain in Spain at the edges of official visibility, marginalized in his household or moving elsewhere. Women thus run the risk of being sent back to Africa by their husbands, sometimes without their children. Gambian children, to the intense frustration of Spanish school officials, tend to be highly mobile as well, leaving when their fathers take jobs elsewhere (Farjas i Bonet 2002) or being sent back to Africa for extended periods to see relatives: usually returning at some point, but occasionally not. ${ }^{30}$

28 The ethnographic materials and analyses in this and the following sections come from our conversations with Gambians in Barcelona, and from our collective experience and that of close acquaintances in both Spain and Africa.

29 The English phrase "forced marriage," which Gambians themselves use even in The Gambia, can be misleading in literal translation. Many of these are simply family-arranged marriages between acquiescent partners.

30 Various observers we spoke to report ethnic variation in these practices, with the Serahulli allegedly practicing more fosterage and more wife and child substitution than the Fula and Mandinka. 
We now turn to the age-sex distribution of Gambians in Spain, relating data from the 2005 municipal register for this immigrant group to findings derived from interviews, conversations, and academic accounts. What is so compelling to watch is how some simple demographic visuals, combined with commentary and other narrative sources, bring to life the exigencies of migration.

In Figure 2, men appear on the left in blue; women, in red, are on the right. The chart also distinguishes between Gambian-born (dark colors) and Spanish-born (light colors) individuals of Gambian nationality. Immigrants who have gained Spanish nationality do not appear in the chart. In the case of Spanish-resident Gambians, like most other African citizens living in Spain, however, the proportion of naturalized citizens is extremely small: just 3 percent. In this, Gambians are typical of other SubSaharan countries. Besides individuals born in Equatorial Guinea, a former Spanish colony, of whom 35 percent of individuals born there are now naturalized Spanish, none of the rest of those registered in Spain who were born in other Sub-Saharan countries are more than 3.4 percent Spanish citizens.

The pyramid depicting Gambian nationals (some of whom might be born in Spain, mostly children) and Gambian-born individuals shows several notable patterns. One is typical for Africans in Europe: a dearth of elders, because so few come from Africa, and many Africans express a desire to return to Africa to retire. There is, however, a disproportionate number of older men, those up to age 49, an unusual feature for a SubSaharan group in Spain, indicating a longer residence for men who likely came as laborers and have settled. We also see a shortage of women and teenagers, particularly compared to what we would see in The Gambia. The most obvious explanation for the shortage of Gambian women and teenagers is that family reunification has been an option only within the last decade for most foreign workers. There are, however, more Gambian women and teenagers in Spain than what we would see in the case of, say, Senegalese, a more recent migrant group, and one that has generally not aimed to stay in Spain but to keep going to France, where bringing women under family reunification plans would make more sense. By far, however, the most distinctive attribute of this chart is the presence of so many Spanish-born Gambian children who do not have Spanish citizenship). 


\section{Figure 2: Gambian nationals and Gambian-born foreigners in Spain}

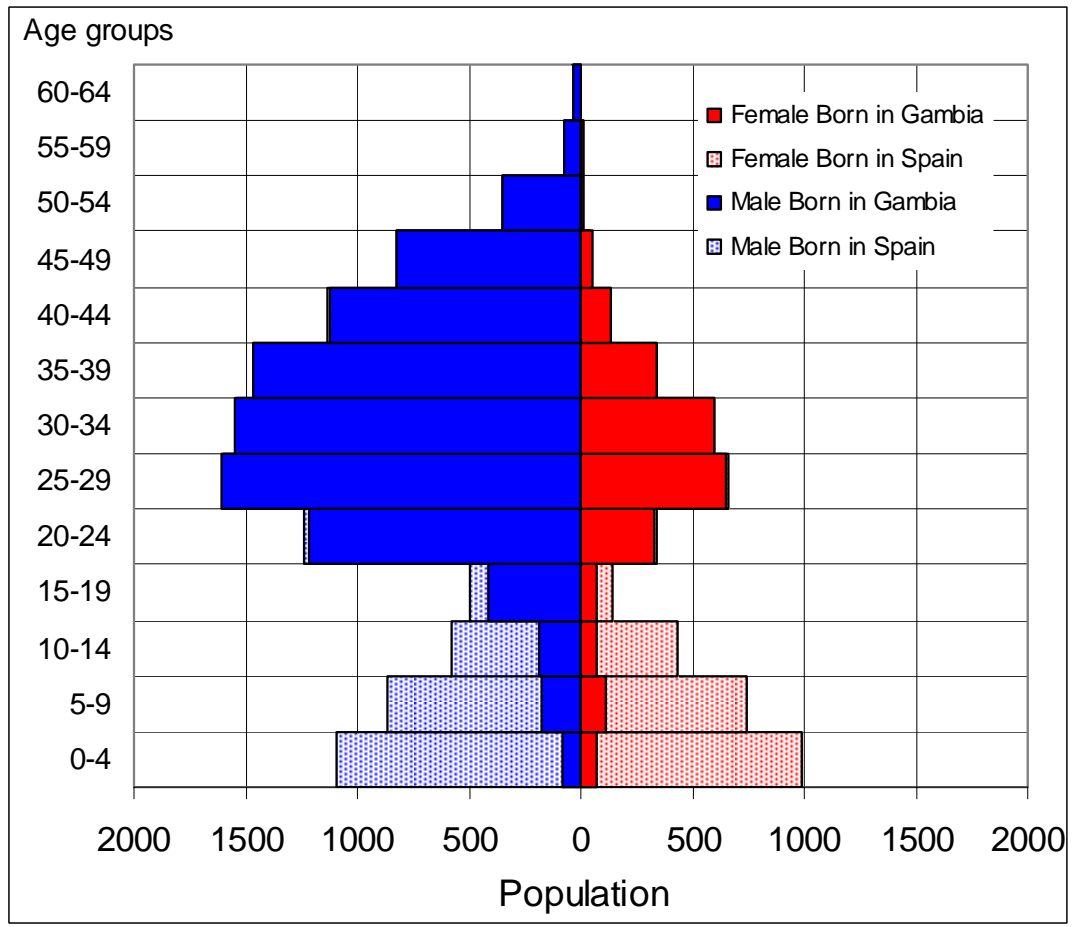

Source: Padrón Municipal. 1 January, 2005

Overall, the Gambian population pyramid in Spain that we see in Figure 2 is quite different from the population of contemporary Gambia, a triangle with even male/female sides and an expanding base. ${ }^{31}$ The bottom, however, is quite similar. One interpretive frame for understanding the excess of Gambian children under 15 - might be a kind of "demography of exclusion," 32 in which the laws and policies intended to affect either the whole population or immigrants in particular may effectively discriminate against some groups, resulting in forms of marginalization that produce particular population outcomes. Given that the proportion of Gambian-born individuals who have become Spanish nationals is so small (0.3 percent), what we may see here is

31 For the pyramid for all of The Gambia in 2005, see http://www.census.gov/cgi-

bin/ipc/idbpyry.pl?cty $=$ GA\&maxp $=205299 \& \operatorname{maxa}=80 \& y \max =250 \& y r=2005 \&$. submit $=$ Submit+Query. 32 For a parallel discussion, see Domingo and Houle (2005). 
the most obvious edge of this discrimination: the children of Gambian immigrants born in Spain who have remained in a kind of naturalization limbo. To better grasp the interpretive puzzles this chart presents for fertility, we need to break down the Gambian pyramid further.

\section{The geography of Gambian fertility in Catalonia}

The following charts compare age-sex pyramids among Gambians in the urbanized provinces of Barcelona-Tarragona (Figure 3) with the regional provinces of Girona and Lleida, or Lérida (Figure 4). ${ }^{33}$ Patterns of particular note emerging in this geographical breakdown of just Catalonia itself reveals unmistakable differences. The graph for Girona-Lleida in particular stands out. While men who are young and in their early middle ages dominate the Barcelona-Tarragona chart, the largest group in GironaLleida is the very young, aged 0-4. In fact, the large proportion of children of Gambian nationality in Girona-Lleida is very much like the stepped expansion in the youthful age groups in rural Gambia. Because we do not have access to Spanish data on foreign populations below the level of the province, some areas that would otherwise be classified as "rural" (or regional) had to be included in the Barcelona-Tarragona graph. If Barcelona were shown separately, we would see an abundance of young Gambian men and a dearth of women and children, while the "rest of Catalonia" would show even more women and children. ${ }^{34}$

The notion of rural-to-rural migration is usually applied to population movement within rural regions of a single country. What Figure 4 instead suggests, along with studies that have traced Gambian immigrants in Spain to areas of eastern Gambia (e.g., Kaplan Marcusán 1998, op. cit.), is an unusual case of rural-to-rural immigration: a group from rural Africa coming to a rural region of another continent. A distinct possibility for Gambians in Spain, especially given the uneducated, unskilled status with which most men come, is that high fertility practices from a rural home context -the current Gambian TFR is 5.5; "World Data Sheet" (www.prb.org) -- may have arisen anew in this rural European locale. ${ }^{35}$

33 The great majority of women in this calculation were born in The Gambia; the register for 1 January 2005 shows only ten Gambian women aged 20-49 who were born in Spain.

34 Thanks to Nuria Empez for suggesting this crucial comparison.

35 Despite the difficult working conditions many African workers must endure in Spain, the rural areas have on the whole been supportive of social services for immigrants and their children, including schooling, health facilities, and child benefits. The efforts by these provinces to gain state assistance for bearing the costs for these young residents as they prepare for productive economic life in Spain would be a key question for policy administrators. 
Figure 3: Gambian nationals and Gambian-born foreigners in Barcelona-Tarragona Provinces. 1 Jan, 2005

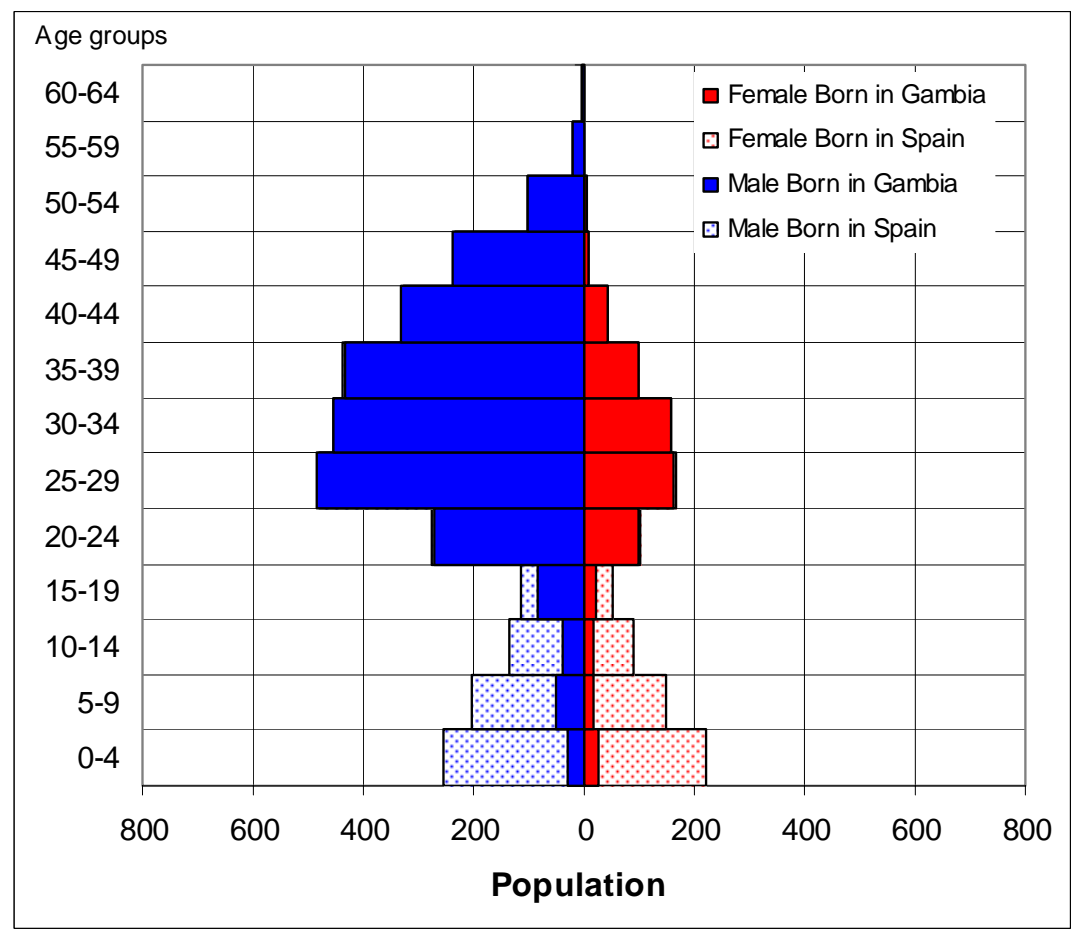

Source: Padrón Municipal. 1 January, 2005 
Figure 4: Gambian nationals and Gambian-born foreigners in Girona-Lleida Provinces. 1 Jan, 2005

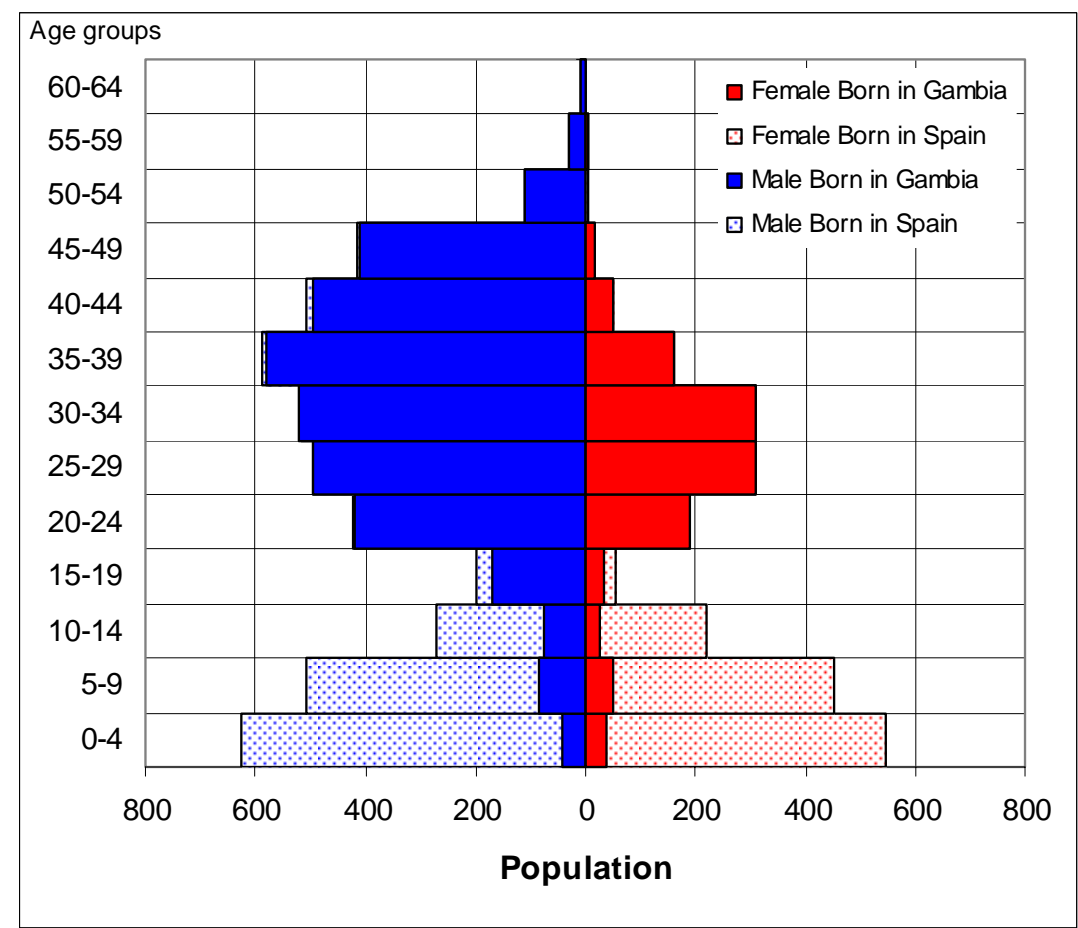

Source: Padrón Municipal. 1 January, 2005 
To be sure, there are terminological problems. In places like The Gambia, the term "rural" has been used in development discourse to refer to areas that are quite different from what we are calling "rural" in Spain. In Spain, our term would include areas where farm managers and workers dominate, but it would also include las cercanías, "surroundings" or "outlying regions." In the case of municipalities like Girona, these contain complex areas with major economic resources in services, tourism and the building sector. Still, population density in these areas is far lower than in Barcelona, as are the costs of housing and food. Available as well in las cercanías are jobs in agriculture, even if the type of farming practiced in these regions is quite different from what Gambians practice in the home country.

If the population pyramids for Gambians in these two areas of Catalonia are so different, total fertility rates among Gambians are equally so (Figure 5). Total fertility rates cannot be ascertained separately for the two sets of provinces; the numbers would be too small. We employ instead an indicator of fertility that is sometimes used when gross population distributions by age and sex are available: the child-woman ratio (CWR), or the ratio between the number of children of both sexes aged 0-4 to women from 20 to $49 .{ }^{36}$ To control for children who may have been left in the country of origin, we included only children born in Spain to Gambian women. Figure 5 shows that while fertility for Gambian women in Spain is much higher than for any other immigrant groups, fertility is significantly higher for Gambian women living in the more rural Girona and Lleida provinces than in Barcelona-Tarragona. The fact that Girona was one of the first places in Spain where Sub-Saharan immigrants came, plus the rural nature of Girona and Lleida, suggests that the fertility of Gambians here may more closely approximate a maturing rural African community. ${ }^{37}$

36 The CWR has serious drawbacks. Among other things, it is affected by the age structure of mothers. Nevertheless, it gives an indication of scale.

37 Thanks to Andreu Domingo for the details of this clarification. 
Figure 5: Child-woman ratio for foreigners in Spain, by country of birth; and for Gambians in Girona-Lleida (Bar-Lle) and Barcelona-Tarragona (BCN-Tar), 2005

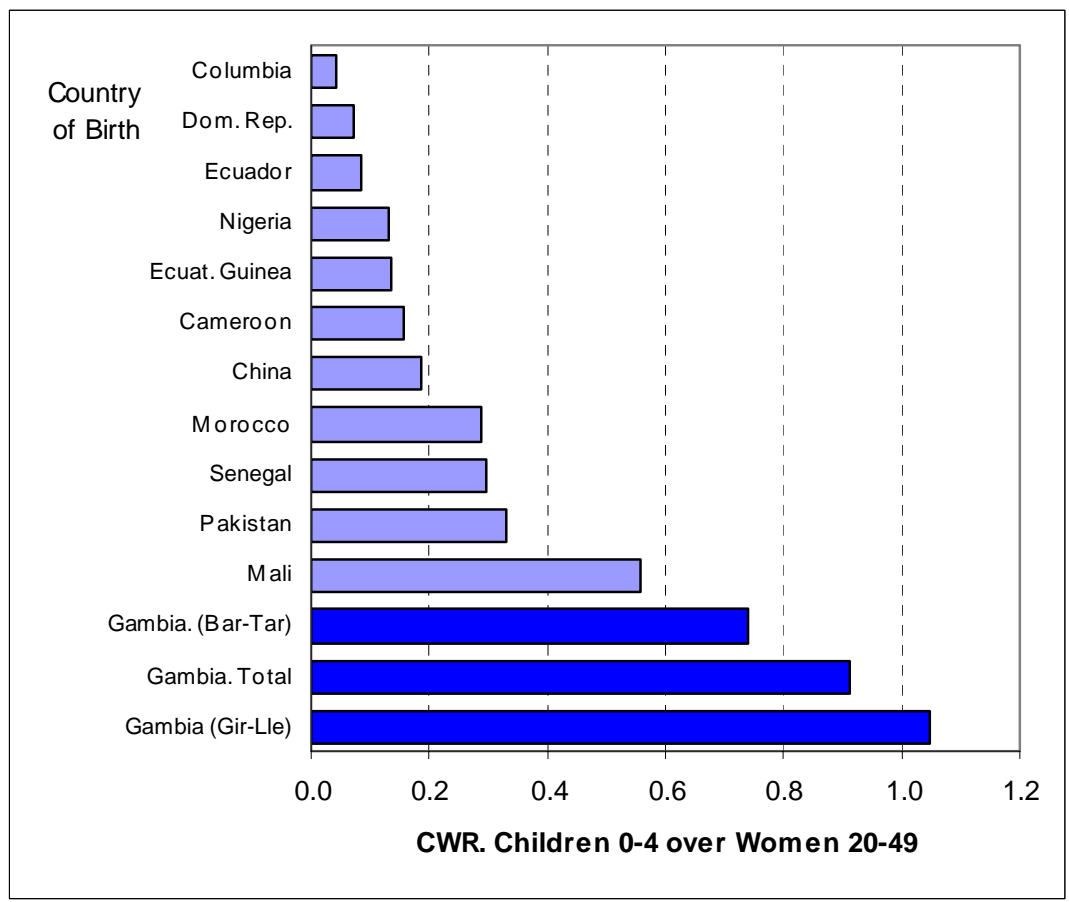

Source: Padrón Municipal. 1 January, 2005

\section{Discussion}

Any attempt to solve the mystery of what appears to be high Gambian fertility in low fertility Spain and to make a case for its broader significance for transnational studies must keep in view several things. One is the tenuous economic status that many Gambians hold in Spain. Another is the African ethnography on the politics of patronage and patterns of circulation for marriage, training, and work. Important as well would be the dynamics of movement across an international border: the increasing financial and legal risks surrounding re-entry that marginal migrants confront if they 
seek to leave the country temporarily. Many other sub-Saharan Africans in Spain encounter these same pressures, of course, and their fertility rates, according to the methods we have used, are not even close to those of Gambians. Indeed, we have emphasized the oddity of Gambian migrants in Spain: high fertility in a low fertility European context. It may seem odd to then claim that their story is representative of other Africans and, further, that conclusions of general applicability can be drawn from it. To do so, we return to two points of difference: the time depth of Gambians' presence in Spain and the rural-rural character of the move that many appear to have made.

The first point of difference is the longer history of Gambian men coming to Spain as workers, compared to men from other sub-Saharan countries. Not all Gambian men who came to Spain for work have stayed, of course. But those who did would have had more opportunity to contract marriages with women back home, many of whom could be sent for, once reunification became possible. These men might be further along a polygynous life trajectory, meaning that they might have not just older wives but young wives who could be brought. Hence, the bulging older male segment of the Gambian age-sex pyramid - men who may have lived in Spain for some time and who can afford to bring wives -- may be even more telling for explaining the swollen bottom of the Gambian pyramid than the segments showing women of reproductive age.

The second point of difference that sets Gambians apart from most other immigrant groups is their unusual pathway of rural-to-rural migration to a rural destination from a rural homeland: one with high fertility. Continuing exchanges of people and support between the homeland and the new locale might point to pressure on migrants to sustain such a life in Spain. Those people who did would in turn pose economic limits on where they could live. Gambian men might well prefer to live in a city like Barcelona where they can set up a business, their wives can find ample employment opportunities, and they can expose their children to cosmopolitan life. But with prohibitive costs of living for unskilled families with modest means, little education, and meager skills in either Spanish or Catalan, farm labor and life in the rural areas and regional towns become the default. Taken together, this constellation of elements appears to have produced a large number of children per woman among Gambian families in Spain, especially in the rural areas of Catalonia.

We believe, then, that Gambian women do have high fertility in Spain. But the large ratio of children to women appears to be intensified by a deceptive dynamic set in motion by patterns of movement and settlement among women and children. We consider first that segment of the population that makes up the "denominator" of the fertility calculus: women. According to local reports, the need to circulate people to and from opportunity, within the restrictions encoded in Spanish law has spawned a cultural repertoire of practices that sometimes replace older wives, whether at their wishes or 
despite their resistance, with a continuing cycle of young women (Bledsoe and Sow 2006). To the extent that the intense financial and legal hurdles that Africans face are pressing the Gambian model of marriage toward a new cultural extreme, forms of "circulation" of women in Africa may be moving toward strategies of "substitution" in Spain. If demographic patterns in Spain mirror Gambian life, in which polygyny is more common in rural than in urban areas, the striking regional patterns observed at the rural level may suggest that the rural Girona-Lleida provinces may have more women who stay on as second or marginalized wives. Thus, we are likely seeing a highly "selected" rotating pool of Gambian women in Spain. Circulating in marriage across international boundaries under particular historically specific reunification schemes, this group, with its fluid and selected membership, is perpetually young and ready for marriage and childbearing.

Our chief interest in this paper, however, is children, the "numerator" in the fertility equation. Like women, children are sometimes circulated, though in quite different ways. Local reports suggest that those children represented in the age-sex pyramid are not always the children of the household's women, as a household-based fertility calculation method would assume. Some may be foster children brought from Africa or under the man's name. ${ }^{38}$ The very regularity itself of the Spanish-born base of the Gambian pyramid, however, strongly suggests that at least those under age 15 were indeed born in Spain. Most are probably the "own children" of the man in the household and of his wife in Spain or, in some cases, of a woman in the household who does not appear in the official record. These "man's-own-children" household configurations would be commensurate with African classificatory kinship practices, in which all children of a man are expected to call all his in-married wives, out of respect, "mother." They would also be quite legitimate under Spanish reunification policies. Spain may ban polygyny, but it does not ban the children of polygynous unions.

Also relevant to the numerator (children) is a paradoxical effect of efforts to stiffen boundaries on migration strategies. In works such as those by Massey and others (op. cit.) on the counterintuitive effects of government policies of exclusion on driving up the number of migrants who try to stay lie further clues to the mystery of the large number of Gambian children in Spain. Like Mexicans coming to the U.S., many Gambians might prefer to circulate to Spain for work and visits, rather than to settle there. Yet with the E.U. tightening its borders and raising the financial and legal stakes for migrants of transnational movement, bringing anyone at all from Africa has become a daunting proposition. Gambians who before could have traveled easily between

38 Farjas (2002), whose thesis focuses on children being sent back to The Gambia to stay with relatives, refers briefly to children sent to Spain to join their immigrant parents or relatives. She describes this as a relatively new practice, an observation that makes sense in that family reunification became possible only in the mid-1990s. 
Africa and Spain now encounter increasing odds. There is increasingly less choice for families of such small, insecure means than to curtail movement rather than take the chance that they might be detained on re-entry. Gambian parents, who back home would have circulated their children fluidly among relatives and grandmothers to cope with the demands of sporadic work at odd hours, may now hold on to their children to allay the risk that they or whoever accompanies them across the border may be denied re-entry. The case of the nine-year-old boy who died of malaria soon after returning to The Gambia for a visit is thus often mentioned by Gambians in Spain not only as evidence of the health risk for young children of going back to Africa; it also spoke strongly to the risks to children who might be unable to return.

What we see in the broad base of the Gambian population pyramid, therefore, may well represent an accumulation of children who are intentionally kept out of transnational circulation. If this "re-entry deterrence" hypothesis is right, then Spain's well-known - indeed, highly publicized -- efforts to restrict entry to irregular immigrants and to apprehend those of questionable qualifications may paradoxically increase the number of immigrants who try to stay. This would in turn suggest that Spanish policies of exclusion, in combination with the rule of monogamy, may be setting the pieces of the Gambian fertility equation onto independent pathways from one another, creating a dual pattern, overall, of substitution of wives and retention of children. While children are likely to stay, their mothers are more likely to circulate, either back to Africa or into narrower temporal windows of legal visibility in Spain.

The presence of so many Spanish-born Gambian children in Girona and Lleida suggests that this is where most of the accumulation of children is occurring. With the longest established history of Gambian establishment in Spain, the regions where many Gambians end up are likely the zone of the deepest "frontiers" of Gambian patronage needed to broker the formation of families under the stark conditions that marginal migrants face. Whether these regions are the locales of many Gambian births, or whether they attract parents with large families who need to live in places where they can find jobs and raise children affordably, the possibility that the labor-hungry rural and semi-rural areas of Catalonia become reservoirs for large Gambian families makes consummate sense.

\section{Conclusion}

This paper has used the dynamics surrounding reproductive life of a high fertility group in Spain as a window of inquiry into the magnitude of immigrant struggles in general to manage in a new land. We have argued that the abundance of Spanish-born Gambian children in Spain may turn less on the mechanisms of high fertility, as classically 
conceptualized, than on responses to policies of exclusion -- what Bourdieu (1990) might call the "logic of demographic practice" -- that is generated by the "official" structures themselves. It reflects the paradoxical dynamics of child accumulation as an artifact of Spanish law itself: the "counter-logics" generated by Spanish laws on monogamy, family reunification, and passage across the international boundary as they press on a longstanding, largely-unskilled West African immigrant population.

In this mix of the construction and erosion of social relationships across time and space among members of a marginal migrant group in Catalonia, several elements have stood out. These have included Gambians' efforts to stabilize their situation by bearing Spanish-born children; a tendency for Gambian men to accumulate a pool of children from a sequence of mothers; and reports that unskilled Gambian workers accept lowwages in "rural" or "regional" destinations in Spain in return for the hope of affordable living conditions, patronage connections, and greater official tolerance. The more explicitly legal elements in the mix have been the ban on having more than one spouse at a time, the 18 year old age boundary for bringing children in family reunification, and increasingly stringent controls on entry for marginal people. Together, these factors appear to have generated the swollen base of the Gambian immigrant pyramid, particularly in the more economically affordable regions of Catalonia, resulting in an accumulation of children who do not circulate back to Africa, whether they are "own" or foster children, or children by multiple wives of the same father.

Throughout we have stressed the importance of understanding local practices from the homeland from which migrants come in order to grasp their practices in the new place. This does not imply, in the present case, that the practices that generate the high ratio of children of Gambian women in Spain stems from efforts by migrants from a high fertility homeland to resume their previous reproductive practices in ways that transcend locale. Nor does the apparent re-emergence of a "traditional" African age-sex pyramid in contemporary Spain imply that such numbers can be read in straightforward ways. The press of Spanish policies force Gambians in Spain to maintain social connections with their homeland by circulating their members through marriage, childbearing, and patronage networks. What seems very salient is that immigrants in conditions of growing marginality must remain deeply connected with their rural homeland through fluid exchanges of people. Understanding emerging Afro-Iberian fertility requires understanding not only the old and new contexts but the dynamics of selection and exclusion that entail close interaction with reproductive regimes in the home country itself.

The current international focus on transnationalism and on African/European immigration make the issues that have emerged in this paper timely. Indeed, if European policies that place restrictions on the free movement of people are resulting in increasing numbers of children of Gambian migrants through processes of 
accumulation, the same patterns may begin to appear among other African groups whose members begin to engage in family reunification on the same scale. ${ }^{39}$ What seems most salient to us, though, is that the domain of children is where the greatest scope for movement into and out of the country for people with tenuous legal status (see also Empez and Galea Montero 2005): a level of flexibility that Gambians as much as anyone need. Children tend to be the people toward whom greatest leniency is shown because of humanitarian ethics. They are also not locked into jobs as men are, nor are they responsible formally, as women are, for the care of a household. While this kind of flux is commonplace in Africa, it takes on a very different character in Europe, where its potential for exploitation becomes more visible and is viewed with less tolerance. Given both the precariousness of farm employment in Spain and the pressure to bring more people as conditions in Africa worsen, the more that Europe tries to seal out Africans, the more "African" their reproductive practices may become. We predict, then, that forces of exclusion will lead to more maneuvering, not less, around children and reproduction, by international, national, and family players.

\section{Acknowledgements}

We thank the Max Planck Institute for Demographic Research for support of this project. We are indebted as well to many people who helped during the study and the analysis, and whose insights as well as generosities of time and engaged critique have been pivotal. Among them are Gunnar Andersson, Yussuf Badji, Pau Baizan, Laura Bernardi, Adama Bojang, Jalika Bojang, Anna Cabré, Bully Diawara, Andreu Domingo, Nuria Empez, Albert Ficat, Vicent Fouda, Anna Jeremies, Adriana Kaplan Marcusán, Boury Marianne Rosalie Mendy, Ferran Moreno, Vicens Galea Montero, Merixtell Pérez, Dan Rodríguez García, Augustin Senghor, Mohamad Saybo Silla, Alassane Silla, Montse Solsona, Andres Vikat, Josep Vilarmau, and Ana M. Zaragoza Bas.

We are also grateful to Laura Bernardi and Inge Hutter for organizing the workshop on "Anthropological Demography" at the Max Planck Institute in Rostock where this study was first presented.

39 Though the circumstances and networks would make their cases less pronounced, the most likely predictions would include Senegalese and Moroccans. Both groups have already reported a substantial number of very young Spanish-born children, as reflected in the Spanish-born sections of the bottom bars of their graphs. 


\section{Bibliography}

Anderson, Bridget. (2000). Doing the Dirty Work? The Global Politics of Domestic Labour. London: Zed Books.

Andersson, Gunnar. (2004). "Childbearing after migration: fertility patterns of foreignborn women in Sweden." International Migration Review 38(2):747-775.

Anthias, Floya and Gabriella Lazaridis, eds. (2000). Gender and Migration in Southern Europe: Women on the Move. Oxford: Berg.

Barnes, Sandra T. (1987). "The urban frontier in West Africa: Mushin, Nigeria." In: Igor Kopytoff, ed. The African Frontier: the Reproduction of Traditional African Societies. Bloomington: Indiana University Press. Pp. 255-281.

Beck, Ulrich. (2000). What is Globalization? Cambridge, Massachusetts: Polity Press.

Bledsoe, Caroline. (1990) “"No success without struggle': social mobility and hardship for Sierra Leone children." Man (N.S.) 25(1):70-88.

Bledsoe, Caroline. (1995). "Marginal members: the problem of children of previous unions in Mende households in Sierra Leone." In Susan Greenhalgh, ed. Situating Fertility: Anthropology and Demographic Analysis. Cambridge: Cambridge University Press. Pp. 130-53.

Bledsoe, Caroline H. (ms.). "Acts of selection: reproduction and risk in contemporary America." Paper presented at Conference on The Political and Symbolic Implications of Quantification. Working Group on Anthropology and Population. Brown University, February, 2004.

Bledsoe, Caroline H. (2004). "Reproduction at the margins: migration and legitimacy in the New Europe." In Gunnar Andersson and Gerda Neyer, eds., Demographic Research: Special Collection 3, Rostock, Germany. Pp. 85-116.

Bledsoe, Caroline H., with contributions by Fatoumatta Banja. (2002). Contingent Lives: Fertility, Time and Aging in West Africa. Chicago: University of Chicago Press.

Bledsoe, Caroline H. and Papa Sow. (2006). "Emancipation or Marginalization: the Dilemmas of Aging Gambian Women in Spain." Paper for the European Population Conference. Liverpool, England.

Bongaarts, John. (1978). "A framework for analyzing the proximate determinants of fertility." Population and Development Review 4(1):105-32. 
Bourdieu, Pierre. (1990). The Logic of Practice. Stanford: Stanford University Press.

Cabré, Anna. (1999). El Sistema Català de Rreproducció. Barcelona: Proa.

Clignet, Remi. (1970). Many Wives, Many Powers: Authority and Power in Polygynous Families. Evanston, IL: Northwestern University Press.

Coleman, David A. (1994). "Fertility and immigration among immigrant populations as measures of integration." Journal of Biosocial Sciences 26(1):107-136.

Comaroff, John L. and Simon Roberts. (1977). "Marriage and extra-marital sexuality: the dialectics of legal change among the Kgatla." Journal of African Law 21(1):97-123.

Constable, Nicole. (1999). "At home but not at home: Filipina narratives of ambivalent returns." Cultural Anthropology 14(2): 203-228.

Dinan, Carmel. (1983). "Sugar daddies and gold-diggers: The white-collar single women in Accra." In C. Oppong, ed. Female and Male in West Africa. London: George Allen \& Unwin. Pp. 344-366.

Domingo, Andreu, Jaume Clapes Estrada, and Maria Prats Ferret. (1995). Condicions de Vida de la Població d'origen Africa $i$ Latinoamericà a la Regió Metropolitana de Barcelona: Una Aproximació Qualitativa. Barcelona: Mancomunitat de Municipis de l'Àrea Metropolitana de Barcelona y Diputació de Barcelona.

Domingo, Andreu, Ines Brancos i Coll, Jordi Bayona i Carrasco. (2002). Migracions Internacionals $i$ Poblacio Jove de Nacionalitat Estrangera a Catalunya. Generalitat de Catalunya, Departament de la Presidencia, Secretaria General de Joventut, Generalitat de Catalunya, No. 7.

Domingo, Andreu and René Houle. (2005). "The economic activity of foreign population in Spain: between complementarity and exclusion." Paper for the International Union for the Scientific Study of Population. 25th International Population Conference. Tours, France. July 18-23, 2005

Domingo, Andrew y I. Brancos. (1996). "Aspectes demogràfics de la immigració estranjera a les comarques barcelonines.” Papers de Demografia, 116, Barcelona: Universitat Autònoma de Barcelona, Centre d'Estudis Demogràfics.

Durkheim, Emile. (1915). The Elementary Forms of the Religious Life. London: Allen \& Unwin. 
Empez, Nuria and Vicens Galea Montero. (2005). "Family strategies and unaccompanied migrant minors." Paper for the European Association of Population Studies, Working Group on the Anthropological Demography of Europe. Max Planck Institute for Demographic Research. Rostock, Germany.

Enel, Catherine, Gilles Pison, and Monique Lefebvre. (1994). "Migration and marriage change: a case study of Mlomp, a Joola village in southern Senegal." In: Caroline Bledsoe and Gilles Pison, eds. Nuptiality in Sub-Saharan Africa: Contemporary Anthroplogical and Demographic Perspectives. Pp. 92-113.

Evans-Pritchard, E. E. (1940). The Nuer: A Description of the Modes of Livelihood and Political Institutions of a Nilotic People. Oxford: Clarendon.

Farjas i Bonet, Anna. (2002). El Process Migratori Gambià a Comarques Gironines: El Cas de Banyoles, Olot i Salt. Doctoral Thesis presented at the Department de la Pedagogia, Universitat Girones.

Fleischer, Annett. (2005). "The influence of family and kin network on the decision to migrate: some evidence from Cameroon." Paper for the European Association of Population Studies, Working Group on the Anthropological Demography of Europe. Max Planck Institute for Demographic Research. Rostock, Germany.

Glick-Schiller, Nina and Georges Fouron. (2001). Georges Woke Up Laughing: Long Distance Nationalism and the Search for Home. Durham, NC: Duke University Press.

Goody, Esther N. (1973). Contexts of Kinship: an Essay in the Family Sociology of the Gonja of Northern Ghana. Cambridge: Cambridge University Press.

Guyer, Jane I. (2004). Marginal Gains: Monetary Transactions in Atlantic Africa. Chicago: University of Chicago Press.

Halbwachs, Maurice. (1980). The Collective Memory, trans. F. J. Ditter Jr. and V. Y. Ditter. New York: Harper \& Row.

Hoggart, Keith and Cristóbal Mendoza. (2000). "African immigrant workers in Spanish agriculture." Working Paper No. 2, Center for Comparative Immigration Studies. La Jolla, California.

Johnson-Hanks, Jennifer. (2006). An Uncertain Honor: Modern Motherhood in an Economic Crisis. Chicago: University of Chicago Press.

Kaplan Marcusán, Adriana et al. (2000-2002). "Salud reproductive de las mujeres migrantes africanas in España: retos e implicaciones para las actuaciones 
públicas socio-sanatarias." Memoria Final de Investigatión. Vol. 1. Centro d'Estudis Demogràfics, Universitat Autònoma de Barcelona.

Kaplan Marcusán, Adriana. (2001). "Integración social, identidad étnica y género: la salud sexual y reproductiva de las mujeres migrantes subsaharianas: retos e implicaciones.” Comunicación del II Congreso sobre la inmigración en España.

Kaplan-Marcusán, Adriana. (1998). De Senegambia a Cataluña: Procesos de Aculturación e Integración Social. Barcelona: Fundación "la Caixa."

Kaplan Marcusán, Adrianna. (Ms.). "Procesos migratorios, transformaciones culturales e identitarias: Senegambianos en Cataluña."

Kopytoff, Igor. (1987). "The internal African frontier: the making of African political culture." In Igor Kopytoff, ed. The African Frontier: the Reproduction of Traditional African Societies. Bloomington: Indiana University Press. Pp. 3-84.

Krissman, Fred. (2005). 'Sin coyote ni patron: why the 'migrant network' fails to explain international migration." International Migration Review 39(1):4-44.

Kulu, Hill. (2005). "Migration and fertility: competing hypotheses re-examined." European Journal of Population 21(1):51-87.

Lalou, Richard and Victor Piché. (2004). "Les migrants face au sida: entre gestion des risques et contrôle social: l'exemple de la vallée du fleuve Sénégal." Population 59(2):233-68.

Lamont, Michèle and Virág Molnár. (2002). "The study of boundaries in the social sciences." Annual Review of Sociology 68:167-95.

Lardoux, Solène and Étienne van de Walle. (2003). "Polygyny and fertility in rural Senegal." Population 58(6):717-44.

Levitt, Peggy and Nina Glick Schiller. (2004). "Conceptualizing simultaneity: a transnational social field perspective on society." International Migration Review 38(3):1002-039.

Locoh, Thérèse. (1994). "Social change and marriage arrangements: new types of union in Lomé, Togo." In: Caroline Bledsoe and Gilles Pison, eds. Nuptiality in SubSaharan Africa: Contemporary Anthropological and Demographic Perspectives. Oxford: Clarendon Press. Pp. 215-230.

Martínez Veiga, Ubaldo. (1999). "Immigrants in the Spanish Labour Market." In: M. Baldwin-Edwards and J. Arango, eds. Immigrants and the Informal Economy in Southern Europe. London: Frank Cass. Pp. 105-128. 
McMurray, David A. (2001). In and Out of Morocco: Smuggling and Migration in a Frontier Boomtown. Minneapolis: University of Minnesota Press.

Massey, Douglas S., Jorge Durand, and Nolan J. Malone. (2002). Beyond Smoke and Mirrors: Mexican Immigration in an Era of Free Trade. New York: Russell Sage Foundation.

Massey, Douglas. (2004). "Economic and social aspects of migration." Annals of the New York Academy of Sciences 1038(1):206-212.

Massey, Douglas S. (2005). "Five myths about immigration: Common misconceptions underlying U.S. Border-enforcement policy. Immigration Policy in Focus 4(6). http://www.ailf.org/ipc/policy_reports_2005_fivemyths.shtml

Merino Tejada, Marta. (2003). "Fecunditat de dones migrants subsaharianes: estudi sobre un col.lectui resident a Mataró precedent de Gàmbia, Senegal i Malí." Departament de Geografia, Universitat Autònoma de Barcelona.

Miret, Pau. (2000). "Fathers and families in contemporary Spain: from dictatorship to democracy." In: Caroline Bledsoe, Susana Lerner, and Jane Guyer, eds. Fertility and the Male Life Cycle in the Era of Fertility Decline. Clarendon: Oxford University Press. Pp. 275-290.

Murphy, William P. and Caroline H. Bledsoe. (1987). "Territory and matrilateral kinship in the history of a Kpelle chiefdom." In: Igor Kopytoff, ed. The African Frontier: The Reproduction of Traditional African Societies. Indiana University Press. Pp. 121-147.

Parkin, David J. and David Nyamwaya, eds. (1987). Transformations of African Marriage. Manchester: Manchester University Press for the International African Institute.

Preston, Samuel H. and Alberto Palloni. (1978). "Fine-tuning Brass-type mortality estimates with data on ages of surviving children." Population Bulletin of the United Nations, No. 10-1977, New York: United Nations. Pp. 72-91.

Randall, Sara and Thomas LeGrand. (2003). "Reproductive strategies and decisions in Senegal: the role of child mortality." Population 58(6):687-715

Recano-Valverde, Joaquin and Andreu Domingo. (2005). "Factores sociodemográficos y territoriales de la inmigración irregular en España." Paper for the International Union for the Scientific Study of Population. 25th International Population Conference. Tours, France. July 18-23, 2005. 
Rodríguez García, Dan. (2001). "Inmigración africana hacia Europa, ¿un proceso sin fin?. El caso de Gambia." Ô Willaeri (La cooperació). Barcelona: ETANE, especial $10^{\mathrm{a}}$ Diada Cultural Afrocatalana, 1, Junio 2001.

Rodríguez García, Dan. (2002). Endogamia, Exogamia y Relaciones Interétnicas: Un Estudio sobre la Formación y Dinámica de la Pareja y la Familia Centrado en Inmigrantes de Senegal y Gambia en Cataluña. Doctoral thesis, Departament d'Antropologia Social i Prehistòria. Universitat Autònoma de Barcelona. (http://www.tdx.cesca.es/TDCat-0223103-184400/)

Rodríguez García, Dan. (2004). Inmigración y Mestizaje Hoy: Formación de Matrimonies Mixtos y Familias Transnacionales de Población Africana en Cataluña. Bellaterra: Universitat Autònoma de Barcelona, Servei de Publicacions.

Roig Vila, Marta and Teresa Castro Martín. (2005). "Immigrant mothers, Spanish babies: longing for a baby-boom in a lowest-low fertility society." Paper for the International Union for the Scientific Study of Population. $25^{\text {th }}$ International Population Conference. Tours, France. July 18-23, 2005.

Ryder, Norman B. (1965). "The cohort as a concept in the study of social change." American Sociological Review 30(6):843-61.

Ryder, Norman B. (1992). "The centrality of time in the study of the family." In: Elza Berquo and Peter Xenos. Family Systems and Cultural Change. Pp. 161-75. Oxford: Clarendon.

Sargent, Carolyn. (2005). "Counseling contraception for Malian migrants in Paris: global, state, and personal politics." Human Organization 64(2):147-56.

Sargent, Carolyn and Dennis Cordell. (2003). "Polygamy, disrupted reproduction, and the state: Malian migrants in Paris, France." Social Science and Medicine 56(9):1961-72.

Sassen, Saskia. (1995). Cities in a World Economy. Thousand Oaks: Pine Forge Press.

Sorensen, Ninna Nyberg. (1994). "Roots, routes and transnational attractions: Dominican migration, gender and cultural change." European Journal of Development Research 6(2)103-118.

Shack, William A. and Elliott P. Skinner, eds. (1979). Strangers in African Societies. Berkeley, California: University of California Press.

Solsona, Montse, Marie do Carmo Fonseca, and Marta Merino. (2003). "Cambio demográfico, migración y salud reproductive: el papel de las mujeres 
senegalesas en la constitutión de las familias." El Quadern CAPS, no. 31. Universitat Autònoma de Barcelona.

Sow, Papa. (2004a). "Prácticas comerciales transnacionales y espacios de acción de los senegaleses in España." Migración y Desarrollo Estudios sobre Remesas y Otros Prácticas Transnacionales in España. Natalia Ribas y Ángeles Ecrivá, eds. Córdoba: Consejo Superior de Investigaciones Científicas, Instituto de Estudios Sociales de Andalucía. Pp. 235-254.

Sow, Papa. (2004b). "Mujeres inmigrantes y/o esposes de inmigrantes senegaleses y gambianos en Cataluña (España): entre la vida familiar y la vida professional." Doc. Anàl. Geogr. 43:69-88.

Stoller, Paul. (2002). Money has No Smell: the Africanization of New York City. Chicago: University of Chicago Press.

Toulemon, Laurent. (2004). "La fecondité des immigrées: nouvelles données, nouvelle approche." Population \& Societé, N. 400.

Turshen, Meredeth, Helene Bretin, and Annie Thebaud-Mony. (1993). "Migration, public policy, and women's experience." In: Meredeth Turshen and Briavel Holcomb, eds. Women's Lives and Public Policy: the International Experience. Westport, CT: Greenwood Press. Pp. 83-96.

Vertovec, Steven. (2004). "Migrant transnationalism and modes of transformation." International Migration Review 38(3):970-1002.

Wallerstein, Immanuel. (1974). The Modern World System: Capitalist Agriculture and the Origins of the European World Economy in the Sixteenth Century. New York: Academic Press.

Whyte, Susan Reynolds. (2005). "Going home? Belonging and burial in the era of AIDS.” Africa 75(2):154-170.

Wimmer, Andreas and Nina Glick Schiller. (2003). "Methodological nationalism, the social sciences, and the study of migration: an essay in historical epistemology." International Migration Review 37(3):576-610

Yavuz, Sutay. (2005). "Fertility transition and the progression to a third birth in Turkey." Paper presented at a workshop on Transnational Vital Events, Rostock, Germany. 
Bledsoe, Houle \& Sow: High fertility Gambians in low fertility Spain 